\title{
APOC3 Gene
}

National Cancer Institute

\section{Source}

National Cancer Institute. APOC3 Gene. NCI Thesaurus. Code C117097.

This gene is involved in the regulation of lipoprotein metabolism and transport. 